\title{
IAMJ
}

INTERNATIONAL

AYURVEDIC

MEDICAL JOURNAL

\section{CLINICAL EVALUATION OF MATRA BASTI OF VARUN TAILA AND KANCHNAR GUGGULU IN VATASTHEELA (BPH)}

\author{
Amit Kumar Gautam ${ }^{1}$, Kainat Ansari ${ }^{2}$, Ketan Mahajan $^{3}$, Sachin Gupta ${ }^{4}$ \\ ${ }^{1}$ PG Scholar Dept. Of Shalya Tantra, Patanjali Bhartiya Ayurvigyan Avum Anusandhan Sansthan, Haridwar, \\ Uttarakhand, India \\ ${ }^{2}$ Assistant Professor Dept. Of Shalya Tantra, Patanjali Bhartiya Ayurvigyan Avum Anusandhan Sansthan, \\ Haridwar, Uttarakhand, India \\ ${ }^{3}$ Associate Professor Dept. Of Panchakarma, Patanjali Bhartiya Ayurvigyan Avum Anusandhan Sansthan, \\ Haridwar, Uttarakhand, India \\ ${ }^{4}$ Professor \& Head Dept. Of Shalya Tantra, Patanjali Bhartiya Ayurvigyan Avum Anusandhan Sansthan, \\ Haridwar, Uttarakhand, India
}

Corresponding Author:amitgautam883@gmail.com

https://doi.org/10.46607/iamj0509112021

(Published Online: November 2021)

Open Access

(C) International Ayurvedic Medical Journal, India

Article Received:07/10//2021 - Peer Reviewed:26/10/2021 - Accepted for Publication:31/10/2021

\section{Check for updates}

\section{ABSTRACT}

Background and Objective: BPH is a senile disorder, which leads to urinary symptoms like incomplete emptying, urgency etc. $90 \%$ of the males over 80 years of age have histological evidence of BPH. Acharya Sushruta has described Vatastheela, as a type of Mutraghata. Owing to the various medical and surgical complications while treating the disease, an Ayurvedic approach using classical medicines in the management of BPH is required. This study was conducted clinical evaluation of Matra Basti of Varun Taila and Kanchnar Guggulu in Vatastheela (BPH). Aim: In this clinical study the aim was to evaluate the effects of Matra Basti of Varun Taila and Kanchnar Guggulu in the management of Vatastheela (BPH). Material and Methods: Random selection of patients was done from OPD of Shalya Tantra Patanjali Ayurved Hospital Haridwar. The study is approved by the ethics and research committee of the same institute vide its latter no PAC/IEC/2018-19/04 and CTRI Registration 
number CTRI/ 2020/11/029404. Based on the Inclusion and exclusion criteria a total of 30 patients were selected. Kanchnar Guggulu 2 TAB BD for 3 months and Varun Talia $72 \mathrm{ml}$ Matra Basti for 1week. Observation: Assessment was made on subjective and objective parameters. Observations were recorded before and after treatment. The grading of parameters was used for statistical analysis. Results: The results showed marked relief in subjective and objective parameters. Moreover, this therapy was well accepted by all patients and did not cause any hindrance in their daily routine work during period of management. Conclusion: We can conclude that the effects of Matra Basti of Varun Taila and Kanchnar Guggulu were significant and free from any complication. Since this study was on small size sample further evaluation is needed to be done and study should be repeated with large sample for longer duration for its establishment.

Keywords: Varun Taila, Kanchnar Guggulu, Vatastheela, BPH.

\section{INTRODUCTION}

Benign Prostatic Hyperplasia (BPH) is the $4^{\text {th }}$ most commonly diagnosed disease in elderly males aged $\geq 50$ years, after coronary disease, dyslipidaemia, hypertension and type 2 diabetes. BPH is a nonmalignant enlargement of the prostate gland surrounding the urethra, resulting in restriction of urine flow. This in turn leads to a spectrum of obstructive symptoms (hesitancy, a weak and interrupted urinary stream, straining, a sensation of incomplete bladder emptying) and irritative symptoms such as urgency, frequency, nocturia collectively known as lower urinary tract symptoms (LUTS). Being a global problem, several scientific efforts for the management of $\mathrm{BPH}$ have been made in different parts of the world but any constant, reliable, non-invasive and invasive therapy, without any complication, is not acceptable so far. Though the instruments with advanced technology for prostatectomy have been evolved but the vast majority of patients suffering from BPH are about 60 years old where surgery becomes avoidable due to ageing, general complications, economy and general debility due to many other systemic diseases which make them unfit surgery. In view of the above facts, several efforts are being made to find out the replacement of the above modalities of management of BPH with the Ayurvedic therapeutical procedures. In the Ayurvedic system of medicine, there is a vivid description of urinary disorders, among them, Vatastheela, a type of Mutraghata, resembles Benign Prostatic Hyperplasia on the basis of symptoms. According to Ayurvedic concepts, this disease is sup- posed to be a result of vitiation of Apana Vayu which produces a glandular firm swelling like an Astheela ${ }^{l}$, enlarging upward (all around) and obstructing the external orifice (prostatic urethra). The condition is known as Vatastheela and the Basti Chikitsa is considered as the treatment par excellence for Vatic disease. In Ayurvedic classics, Kanchanar Guggulu ${ }^{2}$ has been used effectively in the management of Gandamala, Apachi, Arbuda, Granthi, etc.

\section{AIM \& OBJECTIVES}

1. To explore literature about the Vatastheela in Ayurvedic classics and BPH in modern medical Science.

2. To evaluate the effects of Matra Basti of Varun Taila and Kanchnar Gugguluin Vatastheela (BPH).

3. To provide non-invasive and cost-effective management of BPH.

\section{MATERIALS AND METHODS}

Selection of Patients: The Patients with classical signs and symptoms of Vatastheela (BPH) attending the OPD and IPD of P.G. Department of Shalya Tantra Patanjali Bhartiya Ayurvigyan Evam Anusandhan Sansthan Haridwar were randomly selected for this clinical study irrespective of religion, occupation etc.

\section{Inclusion Criteria:}

- Diagnosed cases of BPH along with lower urinary tract symptoms.

- Age group between 50 - 80 years ago.

Exclusion Criteria: The diagnosed case of Diabetes mellitus, Stricture urethra, Prostate carcinoma, Idio- 
pathic bladder neck obstruction, Bladder neck hypertrophy, Renal failure

No. of Patients: A total of 30 patients were registered for present research work.

\section{METHOD OF STUDY}

Prior to the commencement of therapy in the selected patients, general information of the patients and the disease were made as below.

- Research Performa - A detailed Performa was prepared for the study incorporating all the relevant points.

- Informed Consent - An informed written consent was obtained from all included subjects.

\section{Criteria for Diagnosis}

\section{Diagnostic criteria}

- Patients have the signs and symptoms of Vatastheela (BPH).

- IPSS - International Prostate Symptom Score (Based on guidelines of the American Urological Association) was used to assess subjective complaints of the patient before and after the therapy.

- USG finding of the prostate gland size volume and Post Voidal Residual Urine Volume (PVRUV) before and after therapy.

Investigations: Blood Examination (S.PSA), Urine Examination, Plain X-ray of K.U.B, Ultrasonography (USG) of abdomen and pelvis (pre and post void)

Intervention:

(a) Kanchnar Guggulu: $500 \mathrm{mg}$ (2 tabs), 1 tab $=250$ $\mathrm{mg}$, BD for 3 months, with lukewarm water, half an hour after a meal.

(b) Varun Taila: 11/2 pala (72 ml) OD for 1 week, just after breakfast.

\section{Preparation of drug}

Preparation of Kanchnar Guggulu: ${ }^{3}$

Raw ingredients like Kanchnar bark, Triphala, Trikatu, and Trijataka are washed with clear water and kept in a dryer for two days. Yaukut and the removal of seeds are done manually. Grinding of all ingredients is done separately into the fine powder. Then fine powder of Kanchnar bark, Triphala, Trikatu, Varun is mixed in the required ratio.

The Guggulu is crushed into small pieces and tied up in the Pottly and dipped in Triphala kwath and placed in the Dolayantra for Swedana until the Guggulu passes into liquid through cotton cloth. The fine powder mixture of all ingredients is mixed with condensed Guggulu and is pounded for a full day. The pounded mixture is placed in the Guggulu pill making machine. The pills are preserved in airtight containers in a dry place.

\section{Preparation of Varun Taila: ${ }^{4}$}

Take $1 \mathrm{~kg}$ Varun Panchnga and $1 \mathrm{~kg}$ Gokshura and make course powder, boil this coarse powder in 10 Lt. Water and when $5 \mathrm{Lt}$. remain, pour $15 \mathrm{Lt}$. Tila Taila in this decoction and boil until all moisture evaporated and complete Tailapak. Then filtered and Packed plastic container.

\section{Procedure (Matra Basti)}

The procedure of administration of Basti, in general, can be divided into three stages, as follows:

Purva Karma; - The patients will be instructed to come after a light diet (neither to Snigdha nor too Ruksha, and not more than three-fourth of their usual diet). They will also be advised to come after the elimination of stools and urine. The patients will mainly be subjected to local Abhyanga and Mridu Swedana prior to the administration of Matra Basti.

Pradhana Karma; - After Purva Karma, the patient will be advised to lie down in the left lateral position on the Basti (enema) table with the left lower extremity kept straight and the right lower extremity flexed at the knee and hip joints. The patient will ask to keep his left hand below the head. Varun Taila will apply to the anus in a small amount. 72 millilitres of lukewarm Varun Taila will be taken in an enema syringe and a rubber catheter lubricated with Varun Taila was attached to the enema syringe. After expelling the air from the enema syringe, the rubber catheter will be passed through the anus of the patients up to the length of 4 inches. The patient will be asked to take deep breaths and to lie still while the catheter, and the drug, will be introduced. The total amount of Taila will not be administered in order to avoid the entrance of Vayu into the Pakwashaya.

Pashchat Karma; - After the administration of Basti, the patient will be advised to lie in a supine position with the arms and legs spread out freely over the ta- 
ble. Both legs will be raised for a few minutes so as to raise the waist and gently tapped over the hips. Simultaneously, gentle taps will also give on his soles and over the elbow and palms so that the Matra Basti would spread throughout the body and be retained for the required period. After some time, the patient will advise to get up from the table and rest in his bed but to avoid sleeping during the day. Basti Pratyagamana Kala was noted in each case.
Assessment Criteria: The assessment will be done on the subjective and objective parameters and scoring will be done before and after the treatment.

1) Subjective Parameters: The symptoms of $\mathrm{BPH}$ will be recorded on the basis of the International prostate symptom score (IPSS) and analysis will be done on the standard method of statistics.
International prostate symptoms score (IPSS) -

\section{Symptoms}

1. Incomplete emptying

2. Frequency

3. Intermittency

4. Urgency

5. Weak stream

6. Straining

7. Nocturia

\section{Total score:}

$0-7$

8-19

20-35

\section{Score / Grade}

Not at all 0/G0

1 time in 5 micturition $1 / \mathrm{G} 1$

Less than half time $2 / \mathrm{G} 2$

About half the time 3/G3

More than half the time 4/G4

Almost always 5/G5

2) Objective Parameters:

\section{A. Prostate Size Volume:}

\begin{tabular}{|l|l|}
\hline Grade 0 & Up to Normal $(20 \mathrm{cc})$ \\
\hline Grade 1 & $>20$ to $30 \mathrm{cc}$ \\
\hline Grade 2 & $>30$ to $40 \mathrm{cc}$ \\
\hline Grade 3 & $>40$ to $50 \mathrm{cc}$ \\
\hline Grade 4 & $>50 \mathrm{cc}$ \\
\hline
\end{tabular}

B. Post Voidal Residual Urine Volume (PVRUV):

\begin{tabular}{|l|l|}
\hline Grade 0 & Nil (up to $30 \mathrm{cc}$ ) \\
\hline Grade 1 & $>30$ to $60 \mathrm{cc}$ \\
\hline Grade 2 & $>60$ to $90 \mathrm{cc}$ \\
\hline Grade 3 & $>90$ to $120 \mathrm{cc}$ \\
\hline Grade 4 & $>120 \mathrm{cc}$ \\
\hline
\end{tabular}

Assessment of the total effect of therapy - The overall assessment was calculated on the basis of average improvement in terms of percentage relief of scores.

1. Complete remission $-100 \%$
Mildly Symptomatic Moderately Symptomatic

Severely Symptomatic 


\section{OBSERVATION AND RESULTS}

Table 1: IPSS wise distribution of 30 patients of Vatastheela

\begin{tabular}{|l|l|l|}
\hline Symptoms & Number of patients & Percentage \\
\hline Incomplete emptying & 25 & 83.33 \\
\hline Frequency & 29 & 96.66 \\
\hline Intermittency & 18 & 60 \\
\hline Urgency & 25 & 83.33 \\
\hline Weak stream & 23 & 76.66 \\
\hline Straining & 24 & 80 \\
\hline Nocturia & 26 & 86.66 \\
\hline
\end{tabular}

Table 2: Prostate size grade wise distribution of 30 patients of Vatastheela

\begin{tabular}{|l|l|l|}
\hline Prostate size volume grade & Number of patients & Percentage \% \\
\hline Grade 0 (Up to Normal 20 cc) & 00 & 00 \\
\hline Grade 1 (>20 to 30 cc) & 12 & 40 \\
\hline Grade $2(>30$ to 40 cc) & 07 & 23.33 \\
\hline Grade 3 (>40 to 50 cc) & 05 & 16.66 \\
\hline Grade 4 (>50 cc) & 06 & 20 \\
\hline
\end{tabular}

Table 3: Post voidal residual urine volume grade wise distribution of 30 patients of Vatastheela

\begin{tabular}{|c|c|c|}
\hline Post voidal residual urine volume grade & Number of patients & Percentage $\%$ \\
\hline Grade 0 (Nil up to $30 \mathrm{cc}$ ) & 17 & 56.66 \\
\hline Grade 1 ( $>30$ to $60 \mathrm{cc}$ ) & 06 & 20 \\
\hline Grade 2 ( $>60$ to $90 \mathrm{cc}$ ) & 03 & 10 \\
\hline Grade 3 ( $>90$ to 120 cc) & 02 & 6.66 \\
\hline Grade 4 (>120 cc) & 02 & 6.66 \\
\hline
\end{tabular}

\section{RESULTS}

\section{Effect on Subjective parameters}

Table 4: Effect on Subjective parameters

\begin{tabular}{|l|l|l|l|l|l|l|l|}
\hline \multirow{2}{*}{} & \multirow{2}{*}{ N } & \multicolumn{2}{|c|}{ Mean } & \% Effect & W Value & P & Result \\
\cline { 3 - 7 } & & BT & AT & & & Value & \\
\hline Incomplete Emptying & 25 & 2.4 & 0.33 & $77 \%$ & -4.521 & $<0.0001$ & HS \\
\hline Frequency & 29 & 3.9 & 1.23 & $68 \%$ & -4.801 & $<0.0001$ & HS \\
\hline Intermittency & 18 & 1.5 & 0.33 & $78 \%$ & -3.808 & $<0.0001$ & HS \\
\hline Urgency & 25 & 2.5 & 0.83 & $66 \%$ & -4.430 & $<0.0001$ & HS \\
\hline Straining & 24 & 2.3 & 0.76 & $66 \%$ & -4.269 & $<0.0001$ & HS \\
\hline Weak Stream & 23 & 2.4 & 0.8 & $66 \%$ & -4.348 & $<0.0001$ & HS \\
\hline Nocturia & 26 & 2.5 & 0.86 & $62 \%$ & -4.524 & $<0.0001$ & HS \\
\hline Total Score & 30 & 17.6 & 5.43 & $69 \%$ & -4.795 & $<0.0001$ & HS \\
\hline
\end{tabular}


Effect on objective parameters

Table 5: Effect on prostate size volume

\begin{tabular}{|l|l|l|l|l|l|l|l|l|l|}
\hline & \multirow{2}{*}{$\mathbf{N}$} & \multicolumn{2}{|c|}{ Mean } & \% Effect & SD & SE & T Value & P Value & Result \\
\hline & & BT & AT & & & & & & \\
\hline PROSTATE SIZE VOL. & 30 & 2.16 & 0.83 & $61 \%$ & 0.69 & 0.12 & 9.63 & $<0.0001$ & HS \\
\hline
\end{tabular}

Table 6: Effect on Post voidal residual urine volume

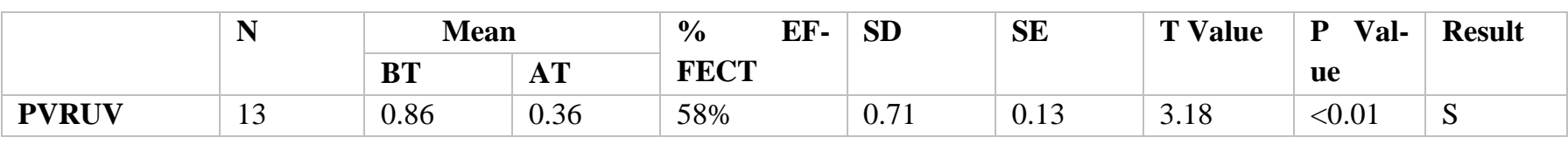

The overall effect of therapy

Table 7: Overall effect of therapy

\begin{tabular}{|l|l|l|l|l|l|l|}
\hline Parameters & \multicolumn{2}{|c|}{ Effect on IPSS } & \multicolumn{2}{c|}{ Effect on prostate size volume } & \multicolumn{2}{c|}{ Effect on PVRUV } \\
\hline The overall effect of therapy & $\mathrm{N}$ & $\%$ & $\mathrm{~N}$ & $\%$ & $\mathrm{~N}$ & $\%$ \\
\hline Complete improvement & 00 & 00 & 10 & 33.3 & 05 & 38.4 \\
\hline Marked improvement & 10 & 33.3 & 00 & 00 & 00 & 00 \\
\hline Moderate improvement & 20 & 66.6 & 06 & 20 & 00 & 00 \\
\hline Mild improvement & 00 & 00 & 12 & 40 & 05 & 38.4 \\
\hline Unchanged & 00 & 00 & 02 & 6.66 & 03 & 23 \\
\hline
\end{tabular}

\section{DISCUSSION}

Matra Basti is the procedure to control Vata Dosha, especially Apana Vata. All Acharyas have recommended Matra Basti as a line of management of Mutraghata to improve urinary function and to remove the obstruction. Matra Basti possesses Balyakarak to the Basti Snayu. This helped to improve the tone of the bladder and ultimately resulted in Samprapti Vighatana of Vata Vridhi. There was a significant decrease observed in post-voidal residual urine volume was observed. The effect was significant because of the short duration of therapy and weakness in detrusor muscles generally found in old age.

\section{Mode of action Kanchnar Guggulu}

Kanchnar Guggulu possesses the properties of VataKapha Shamana, Pachana, Basti Shodhana and Mu$\mathrm{tral}^{6}$. This property helped to enhance the function of the bladder. It also helped in reducing the size of the prostate gland. Ingredients of Kanchnar Guggulu like Triphala and Trikatu helped to relax the smooth muscles of the prostate and bladder neck. Thus, relieving the pressure and improving urine flow rate.

\section{Mode of action of Varun Taila}

Varun Taila have some property like Kapha, Vatahara, Bhedana, Vatanulomana, Mutral, Shothahara, and Balya effects. According to Samprapti of Vatastheela deranged functioning of Vata leads to vitiation of other Doshas, Ama formation \& Srotoavarodha. Thus, vitiated Dosha travel through trough the Sukshma Siras and Dhamani to get lodged in (Khavaigunya Sthana) Basti where upon further vitiation of Vata leads to Vimargagaman and therefore Mutraghata. With aided Mutrala and Vatanuloman effects, the drug helps to expel the accumulated $\mathrm{Mu}$ tra with greater force; thus, it will break the Doshdushya Sammurchana of Mutraghata.

\section{CONCLUSION}

The conservative management of Vatastheela and other urological disorders according to Ayurvedic guidelines can yield much better results in comparison to modern conservative management as there is no side effect of Ayurvedic medicine. Finally, the study can be concluded that the use of Kanchnar Guggulu and Varun Taila for Matra Basti in BPH (Vatastheela) is cheap, safe, effective and easily pal- 
atable for patients. Use of it in the early stage of BPH (Vatastheela) can prevent the further progressive pathology of the disease.

\section{Acknowledgement}

Thanks to Dr. Sachin Gupta (HOD) sir, Dr. Kainat Ansari mam, Dr. Ketan Mahajan sir. I thank one and all who helped directly and indirectly in this work

\section{RECOMMENDATIONS}

1. In this study sample size and duration of the treatment was small. So further study should be conducted in large sample size and a large time of treatment is required.

2. In this study, prostate size is measured through abdomen USG, but Trans-Rectal Ultrasound (TRS) can be proved more effective for accurate measurement of prostate size as well as for assessing the effect of the therapy on $\mathrm{BPH}$

\section{REFERENCES}

1. SHUSHRUTA SAMHITA edited with Ayurvedatattva-Sandipika by Kaviraja Ambika dutta Shastri, Chaukhamba Publication Reprint 2010 - Nidanasthana Chapter $1 / 10$ page 305 , Uttratantra Chapter $58 / 7-8$ page 540.

2. Bhaisajya Ratnawali of Govinda Dasji Bhisagratna commented upon by Vaidya Shri Ambika Data Shastri English Translation by Dr Kanjiv Lochan, Chaukhamba Sanskrit Sansthan. Varanasi Edition:Reprint, 2014 Chapter 44/ 64, 65, 66, 67, 68, 69

3. Bhaisajya Ratnawali of Govinda Dasji Bhisagratna commented upon by Vaidya Shri Ambika Data Shastri English Translation by Dr Kanjiv Lochan, Chaukhamba Sanskrit Sansthan. Varanasi Edition:Reprint, 2014 Chapter 44/ 64, 65, 66, 67, 68, 69

4. Bhavaprakasa of Sri Bhamisra Edited with the Vidyotini Hindi Commentary. Vol 2 Pg.No. 381.

5. Ibidem Charaka Samhita (1), Ch. Si. 4/53;701

6. SHUSHRUTA SAMHITA edited with Ayurvedatattva-Sandipika by Kaviraja Ambika Dutta Shastri, Chaukhamba Publication Reprint 2010 - Nidanasthana Chapter 1/10 page 305, Uttratantra Chapter 58/7-8 page 540 .

\section{Source of Support: Nil Conflict of Interest: None Declared}

How to cite this URL: Amit Kumar Gautam et al: Clinical Evaluation Of Matra Basti Of Varun Taila And Kanchnar Guggulu In Vatastheela (BPH). International Ayurvedic Medical Journal \{online\} 2021 \{cited November 2021\} Available from: http://www.iamj.in/posts/images/upload/2671_2677.pdf 